\title{
Addiction and relapse process
}

\author{
Meire Luci da Silva* \\ Professora Doutora da Universidade Estadual Paulista (UNESP) e Tutora da Residência Integrada Multiprofissional em Saúde Mental da Faculdade de Medicina \\ de Marília (FAMEMA), Brazil
}

\section{Editorial}

Currently addiction is characterized as a serious public health problem of world order, affecting all social classes, intellectual levels, cultures, race and, among others. Chemical dependence is a chronic, progressive, and fatal but a treatable disease. It is multiclausal and requires clinical and drug treatment, as well as biopsychosocial interventions, complex and specific to the reality of each dependent (WHO, 1993). Due to the complexity of addiction, during treatment the dependent presents difficulties as to maintain abstinence from substance and manage the emotional obstacles, subjective, social, occupational, and financial, so one of the important factors that aids in the effectiveness of treatment is the voluntary adherence of the dependent to the treatment, since the "wanting to treat" facilitates awareness of the inability and / or difficulties that can lead to relapse.

Relapse is very common during treatment of any dependency, being characterized by the set of symptoms of the disease that reappear after the individual, abstinent from the substance for a period, return to the use of the substance according to the pattern of consumption prior to treatment. Relapse differs from the lapse that is when it is dependent, now abstinent for a while, for a situation returns to use, but in lower amount and isolated form, but quickly returns to treatment. According to statistical surveys conducted by the Health of Ministry [1], the relapse rates are high and indicate that among alcoholics in treatment, $50 \%$ fall in the first six months, of smokers, 70 to $90 \%$ return to smoking in the first six months and cocaine dependents, $45 \%$ fall within the first six months. The high occurrence of relapses points to the ineffectiveness of current treatment approaches and, therefore, the need to think about different and specific intervention strategies with these individuals.

The relapse and consequent perception of the loss of sobriety are related to feelings of helplessness, frustration, disappointment and especially failure, and such feelings are not easy to deal with. Carvalho et al. [2] and Silva, et al. [3] report multiple factors that interfere in the maintenance of abstinence and may lead to relapse, among them, difficulties with negative feelings, relational conflicts, job inactivity, prejudice, places of risk to use, in addition to friends' users.

Still in relation to relapse and during the treatment process, Salles et al. [4] emphasize the importance of the health professional in the provision of the care as a device of attention and listens to the demands and difficulties of the dependent, assisting him in the identification of the risk factors and strengthening of protective factors.

In this context, the family may represent structured support, friends who do not use, the extension pleasant moments without the use of psychoactive substances and strengthening of spirituality can be considered protective factors. Important to emphasize the ambiguity of the family's role in the treatment, being considered a risk factor or protection, it depends on the socio-historical context and familiar of the dependent $[5,6]$.

The episode of relapse is not a choice, but it is intimately and directly related to the dependent's ability to avoid risk factors and to use protective factors. Recognition and awareness of factors that may lead to relapse and those who will protect it, will assist in the planning and design of coping strategies. It is common for the abstinent addict for a while, feel "cured" and resistant to the substance, thinking it can return to using and stop whenever he wants. This false sense of "healing, ability and power" poses a great danger and fragility to relapse. For awareness of its addiction as a chronic disease and of its impotence towards the substance, it is necessary to perceive your inability and incapacity in the face of the substance, because the dependent often has the false sense of control and exposes himself to increasing risks until he returns to use.

Relapse should be discussed openly with the dependent, so that it identifies which led to relapse and thus may start changing their behavior.

Relapse is a challenge not only to the addict that needs to relearn how to be surrounded by non-dependent, dealing with the challenges of a life full of rules, charges and responsibilities and, his family, but society as a whole, where this last one must learn and put into practice, the distance from the judgment of the another's failure, but allow to the dependent, the (re) start, a learning experience, a new opportunity to the one who chose a change.

\section{References}

1. Coordenação Nacional de DST/Aids (2003) A Política do Ministério da Saúde para atenção integral a usuários de álcool e outras drogas / Ministério da Saúde, Secretaria Executiva, Coordenação Nacional de DST e Aids. - Brasília: Ministério da Saúde.

2. Carvalho F R M (2011) Causas de recaída e de busca por tratamento referidas por dependentes químicos em uma unidade de reabilitação. Colombia Médica Cali 42(2): $57-62$.

3. Silva ML, Guimarães CF, Salles DB (2014) Fatores de risco e proteção à recaída na percepção de usuários de substâncias psicoativas. Revista Rene, Ceará 15 (6): 1007-1015.

4. Salles DB, Silva ML (2017) Percepção de profissionais da área de saúde mental sobre o acolhimento ao usuário de substância psicoativa em CAPSad/Mental health professional perception of the embracement towards psychoactive substance user in CAPSad. Cadernos Brasileiros de Terapia Ocupacional 25: 2.

Correspondence to: Meire Luci da Silva, Professora Doutora da Universidade Estadual Paulista (UNESP) e Tutora da Residência Multiprofissional Integrada em Saúde Mental da Faculdade de Medicina de Marília (FAMEMA), Brazil, E-mail: meire@marilia.unesp.br

Received: January 15, 2018; Accepted: January 20, 2018; Published: January 23 2018 
5. Silva ML, Santos NMR, Barnabe V, Valenti VE (2013) Risk factors that may signify a propensity to the use of drugs in students at a public university. Journal of Human Growth and Development 23(3) 346-351.
6. World Health Organization (1993) International Statistical Classification of Diseases and Related Health Problems. Tenth Revision. Geneva: WHO 1993.

Copyright: ${ }^{0} 2018$ Luci da Silva M. This is an open-access article distributed under the terms of the Creative Commons Attribution License, which permits unrestricted use, distribution, and reproduction in any medium, provided the original author and source are credited. 